\title{
El uso de códigos QR y su eficacia en la aplicación de competencias profesionales
}

\section{The use of QR codes and their efficiency in the application of professional skills}

\section{Evgeniya Georgievna Artemova ${ }^{1 a}$, Yulia S. Shishalova ${ }^{2}$, Sergey Evgenievich Melnikov $^{3}$, Oksana Evgenjevna Orekhova ${ }^{4}, \&$ Galina Nikiporets-Takigawa ${ }^{5}$}

\author{
Moscow City University, Moscow, Russia ${ }^{1}$ \\ Russian Presidential Academy of National Economy and Public \\ Administration (RANEPA), Russia ${ }^{2}$ \\ Moscow Automobile and Road Construction State Technical \\ University, Moscow, Russia ${ }^{3}$ \\ Moscow State University of International Relations, Moscow, Russia ${ }^{4}$ \\ Russian State Social University, Moscow, Russia ${ }^{5}$ \\ ORCID ID: https://orcid.org/0000-0002-2850-6674 ${ }^{1}$ \\ ORCID ID: https://orcid.org/0000-0002-9152-1092 2 \\ ORCID ID: https://orcid.org/0000-0003-2050-13313 \\ ORCID ID: https://orcid.org/0000-0003-1930-1666 \\ ORCID ID: https://orcid.org/0000-0002-5611-8396
}

Recibido: 12 de febrero de 2021

Aceptado: 02 de noviembre de 2021

\section{Resumen}

El propósito del estudio es analizar el estado moderno y las perspectivas de uso de la tecnología para la creación y el reconocimiento de códigos QR y verificar experimentalmente la eficiencia y viabilidad de su aplicación en la formación de competencias profesionales de futuros químicos y economistas. Se usaron análisis de literatura científica y metodológica, asi como métodos de diagnóstico (observación, conversaciones, cuestionarios y pruebas) para determinar la eficiencia 
del uso de la tecnología para la creación y el reconocimiento de códigos QR en la enseñanza de los estudiantes. Asimismo, se utilizó un experimento pedagógico para probar empíricamente la eficiencia y viabilidad de su aplicación para aumentar la motivación y el desempeño durante la formación de competencias profesionales de los futuros químicos y economistas; métodos de estadística matemática. El método propuesto de utilizar la tecnología de códigos QR en las actividades educativas, forma y desarrolla competencias profesionales, asegurando un incremento en los indicadores de calidad del proceso educativo. Por lo tanto, los códigos QR se pueden utilizar en el proceso educativo como una herramienta pedagógica interactiva, con lo que se organizan actividades educativas efectivas de los estudiantes.

Palabras clave: Código QR, aprendizaje móvil, tecnología de código QR, proceso de aprendizaje, motivación, educación, tecnología.

\begin{abstract}
The purpose of the study is to analyze the modern state and prospects of using the technology for QR-code creation and recognition and experimentally check the efficiency and feasibility of their application in the professional competence formation of future chemists and economists. Analysis of scientific and methodological literature were used; also, diagnostic methods (observation, conversations, questionnaires, testing) were used to determine the efficiency of apply the technology for QR-code creation and recognition in teaching students. A pedagogical experiment to empirically test the efficiency and feasibility of their application in increasing the motivation and performance during professional competence formation of future chemists and economists were used, as well as methods of mathematical statistics. So, the proposed method of using the technology of QR codes in educational activities forms and develops professional competencies, ensuring an increase in the quality indicators of the educational process. Therefore, QR codes can be used in the educational process as an interactive pedagogical tool, with the help of which effective educational activities of students are organized.
\end{abstract}

Keywords: QR-code, mobile learning, QR-code technology, learning process, motivation, education, technology.

\title{
Introduction
}

According to Ally (2013), mobile learning is a new, modern model of the structure of the educational process, which is characterized by the following components: methodological support for the study of subjects; a mobile-oriented environment for educational resources; teaching staff trained in the use of mobile technologies and familiar with the methodology of mobile learning; equipment and software. Each component is an integral element of the efficient use of mobile devices in the educational process and is the subject of active discussion in the academic community. 
Let us focus our attention on the last component/equipment and software. One of the most relevant ways for using this component is the use of QR-codes: programs for scanning twodimensional bar codes (Chu \& Liu, 2007; Liu et al., 2007; Okazaki et al., 2012; Latif et al., 2012). A QR code is a two-dimensional image in which certain text or numbers are embedded. Visually, it is presented in the form of a black and white square resembling a labyrinth (Fig. 1).

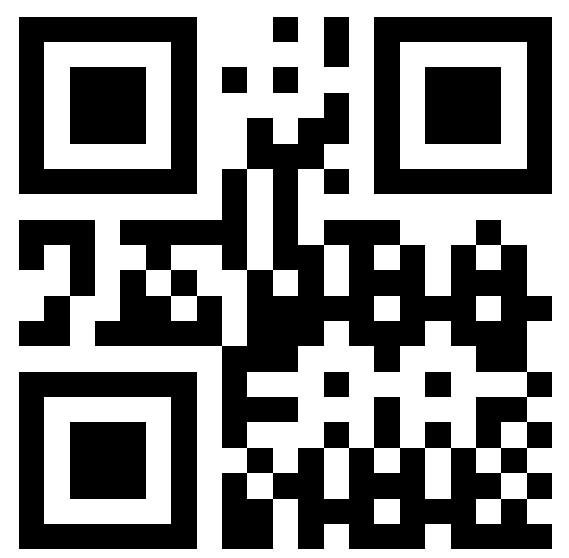

Figure 1. An example of a QR-code

Almost any mobile device easily recognizes and decrypts information encoded using a QR code. First, the program decrypts the code and then offers to perform a certain action provided by the content of the code (Coleman, 2011). The integration of mobile technologies into educational activities can radically modernize the educational process.

The use of QR-codes is associated with some problems that should be considered when introducing this technology into the educational process. Thus, various researchers (Lai et al., 2013; Law \& So, 2010; Monguillot et al., 2014) highlight the advantages and disadvantages of QR-codes. Advantages: storage of large amounts of digital and text data in any language; the speed of creating a QR-code using software tools; high recognizability, while the printed size of the code can be very small; the ability to scan in any direction; almost any surface is suitable for placement; resistance to damage (scanning when the code is damaged up to 30\%). Disadvantages: the relatively high cost of mobile Internet; low awareness of QR-coding technology; technical difficulties.

Some studies like Chang (2014) and Uluyol and Agca (2012) are devoted to possible ways of using QR-codes when creating textbooks through using additional digital resources. One can encode 
the necessary web links to additional digital resources and insert the resulting QR-codes on the pages of the textbook (on the margins next to the mentions of the corresponding digital resources in the text or with the references given in the text of the textbook). When working with such a textbook, the student should only read the necessary QR-code with their own smartphone and immediately get the desired digital resource on the screen to start working with it; also, using animated illustrations. By using the QR-code, one can insert animated illustrations or a link to a short video into a printed book to help the student better understand the topic.

Further, the matters of the efficiency of QR-codes and their use as a potential source of quality education for student youth remain unsolved. Therefore, a modern information technology that can be involved in the learning process is the $\mathrm{QR}$-code technology. At the same time, the issues of the efficient and appropriate use of this technology, and, in particular, smartphones, in the educational process remain open, since there is an opinion that this distracts from the content of educational activities, promotes the formalism of knowledge (Goyal, Yadav, \& Mathuria, 2016).

Therefore, the purpose of the article is to analyze the current state and prospects of using the technology for creating and recognizing QR codes, experimentally testing the effectiveness and appropriateness of their use in the process of forming students' professional competencies. The study hypothesizes that the application of the technology for QR-code creation and recognition in the learning process helps to increase the motivation and learning achievements of students-future specialists. According to the results of the study, one can conclude that the goal set in the study was achieved.

\section{Methods}

\section{Design of the research}

To achieve the goals of the research, a mixed study design was developed. A complex of theoretical and empirical research methods was used. The main research method was a pedagogical experiment (Creswell \& Creswell, 2020). In this study, we used verification of tools for the validity and adequacy of the research objectives (validation). We used variations of criterion validity to understand how the results obtained for one indicator were consistent with the results obtained for another indicator. To build the model of the relationship between the selected criteria, we used construct validation. 


\section{Procedure and instruments}

At the first stage of the study 5 questions were asked: "Are you familiar with the technology of QR codes?”; “Do you use QR codes in your everyday life?”; "In what spheres of life do you most often use QR codes?"; “Have you used QR codes for educational purposes?"; "Would you like to use QR codes in the educational process?"

The questionnaires were compiled by adaptation (modification) based on the tools that were used for similar studies in analyzing the current state and prospects of using technologies in the process of forming students' professional competencies. After preparing the questionnaires, we discussed their reliability and identified their strengths and weaknesses with other monitoring participants. Based on the results of the discussion, we made adjustments to the questionnaires before starting to collect data.

The experiment involved 82 students of Chemistry and Economics in the second and third years. The experimental group included 40 students of the second or third year of studying Chemistry. For the control group, 42 students of Economics in the second and third years were selected. The students had the same number of hours to study the subject chosen for the experiment in the fields of Chemistry (Analytical Chemistry) and Economics (History of Economics), respectively. Students of the experimental and control groups were invited to strengthen their educational activities by using QR-code technologies during the lecture and practical support of chemical and economic subjects, respectively.

An important component of the educational process is the pedagogical implementation and use of mobile technologies. In view of this, the purpose of the experimental study was to empirically test the efficiency and feasibility of using QR-codes as a means of increasing the motivation and learning achievements of students - future chemists and economists (Solovieva et al., 2020).

At the second stage of the study, for experimental verification of the effectiveness and appropriateness of the use of QR codes in the process of increasing the motivation and educational achievements of future chemists in the formation of their professional competencies, a pedagogical experiment was carried out, including pre-experimental and post-experimental diagnostics of students' motivation to study in subject disciplines, in the areas of "chemistry" ("Analytical chemistry") and "economics" ("History of economics"), as well as diagnostics of the level of educational achievements. 
The control of the formation of theoretical knowledge was carried out using tests that we specifically created for each of the studied disciplines (which were used at the beginning, during and at the end of the experiment). Each of the tests in the disciplines studied by the students (“Analytical Chemistry" and "History of Economics") included 15 questions, of which 10 questions involved choosing one correct answer from several answer options and 5 questions - text input of the answer.

The control of the formation of practical skills and abilities was carried out during the execution and grading of competence-oriented tasks in the process of studying subjects and skills as a result of evaluating extracurricular activities, during the study of the topic of QR-codes within the framework of a scientific club, in the form of a QR-quest, QR-quiz, etc.

The levels of students' assimilation of theoretical knowledge and the formation of the ability to solve competence-oriented tasks were determined depending on the ratio of the number of correctly reproduced elements of theoretical knowledge (correct answers) and correctly reproduced elements of competence-oriented tasks (correct decisions) to the total number of questions and input (output) test tasks. It is considered that a student's academic achievements are at a sufficient level when they completed at least $70 \%$ of the tasks offered to them.

\section{Statistic analysis}

To determine the meaningful indicators in the samples of the examined students, the obtained data were calculated using Student's t-test. This criterion reveals trends in changes in a feature when moving from one measurement condition to another. The final values of the experimental and control groups were also compared using the parametric Student's t-test and the total percentage of understanding the material and the degree of competence formation were compared according to the levels of students' understanding of theoretical knowledge and the formation of the ability to solve competence-oriented tasks.

A survey of students in the experimental group conducted before and after work on the implementation of training using the QR-code technology demonstrated significant changes in both interest (temp $=3.725 ; \mathrm{p}<0.01)$ and usefulness assessment (temp $=3.134 ; \mathrm{p}<0.01)$ of the application of the QR-code technology. For the experimental group, the reliable level of differences in the results of the control and establishing stages (temp $=4.087, \mathrm{p}<0.01)$ identified. 


\section{Results}

The results of the preliminary questionnaire showed the following. When answering the question “Are you familiar with QR-code technology?", $85 \%$ of the respondents gave an affirmative answer. 62\% used it in everyday life (mainly for obtaining comprehensive information about goods and services, in the banking or tourism sector). Only 9\% used QR-codes for educational purposes. $100 \%$ of all respondents stated their desire to use them during the educational process. Considering the students' ability to work with modern information technologies and having discovered their willingness to use their own mobile devices in educational activities, we invited the students of the experimental group to take part in a scientific experiment.

At the beginning of the experiment, we determined that in both control and experimental groups, the levels of motivation to study the proposed subjects, as well as theoretical preparedness and formation of practical skills with the requirements for a future chemist and economist, were practically the same. We established such differences at the level of arithmetic means using Student's t-test. After the completion of the experimental work, a repeated study of the students' levels of motivation and learning achievements was carried out. The results of the questionnaires aimed at identifying the motivation of students in the experimental group are presented in Table 1.

\section{Table 1}

Results of identifying the motivation of students in the experimental group

\begin{tabular}{llll}
\hline \multicolumn{1}{c}{ Stage } & Grade & $\begin{array}{l}\text { Interest } \\
\text { \% of sample }\end{array}$ & $\begin{array}{l}\text { Importance scale, } \\
\text { \% of sample }\end{array}$ \\
\hline \multirow{3}{*}{ Before experimental } & 2 & 0 & 0 \\
work & 1 & 10 & 0 \\
& 3 & 15 & 20 \\
& 4 & 50 & 55 \\
After experimental & 5 & 25 & 25 \\
work & 1 & 0 & 0 \\
& 2 & 0 & 0 \\
& 4 & 5 & 0 \\
\hline
\end{tabular}

Note: "1" on the Importance scale corresponds to minimum value ("completely uninteresting", "completely unimportant"), "5" corresponds to maximum value ("very interesting", "very important").

Table 2 shows the results of an experimental study of the level of educational achievements of students in the experimental and control groups. 
Table 2

The results of assessing the level of educational achievements of students

\begin{tabular}{|c|c|c|c|c|c|c|}
\hline \multirow[t]{2}{*}{ № } & \multirow[t]{2}{*}{ Assessment criteria } & \multicolumn{2}{|c|}{$\begin{array}{l}\text { Indicator } \\
\text { experimental work, } \%\end{array}$} & before & \multicolumn{2}{|c|}{$\begin{array}{l}\text { Indicator after experimental } \\
\text { work, } \%\end{array}$} \\
\hline & & $\mathrm{EG}$ & $\mathrm{CG}$ & & $\mathrm{EG}$ & $\mathrm{CG}$ \\
\hline 1 & $\begin{array}{l}\text { the level of assimilation by } \\
\text { students of the theoretical } \\
\text { material of the course } \\
\text { (formation of theoretical } \\
\text { knowledge) }\end{array}$ & 63.13 & 61.7 & & 72.65 & 62.6 \\
\hline 2 & $\begin{array}{l}\text { the level of ability to solve } \\
\text { competence-oriented tasks (the } \\
\text { formation of practical skills and } \\
\text { abilities) }\end{array}$ & 62.52 & 61.3 & & 71.4 & 63.2 \\
\hline
\end{tabular}

Figure 2 shows the levels of students' understanding of theoretical knowledge presented to future chemists and economists, obtained through testing.

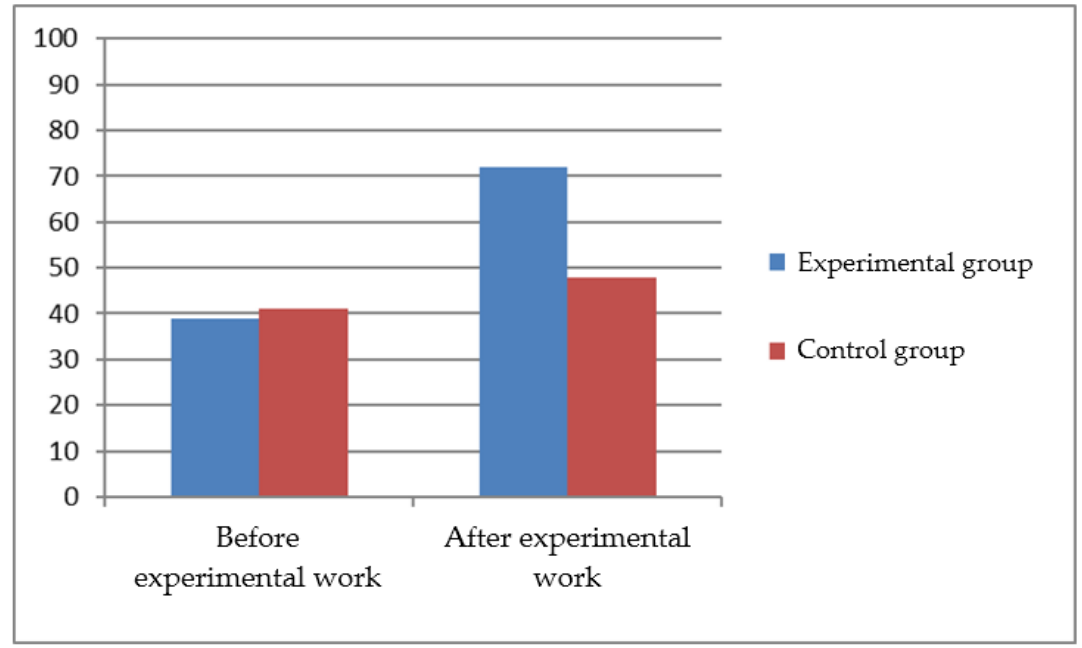

Figure 2. The level of students' understanding of theoretical knowledge during testing (group average, \%)

At the same time, no reliable differences in the results of the control and establishing stages are present in the control group. Thus, the results obtained indicate an increase in the level of understanding of theoretical knowledge among students of the experimental group in the process of 
studying "Analytical Chemistry" and "History of Economics" using the QR-codes technology at various stages of learning. Figure 3 shows the achievements of the students of the experimental group in solving competence-oriented problems. Due to the data comparison, we can state that there was a distinct increase in the level of the ability to solve such problems (temp $=4.158, \mathrm{p}<0.01$ ). From the experimental data, one can see that at the final stage, the level of the ability to solve competence-oriented tasks exceeds the critical limit of $70 \%$ (method of Bespalko).

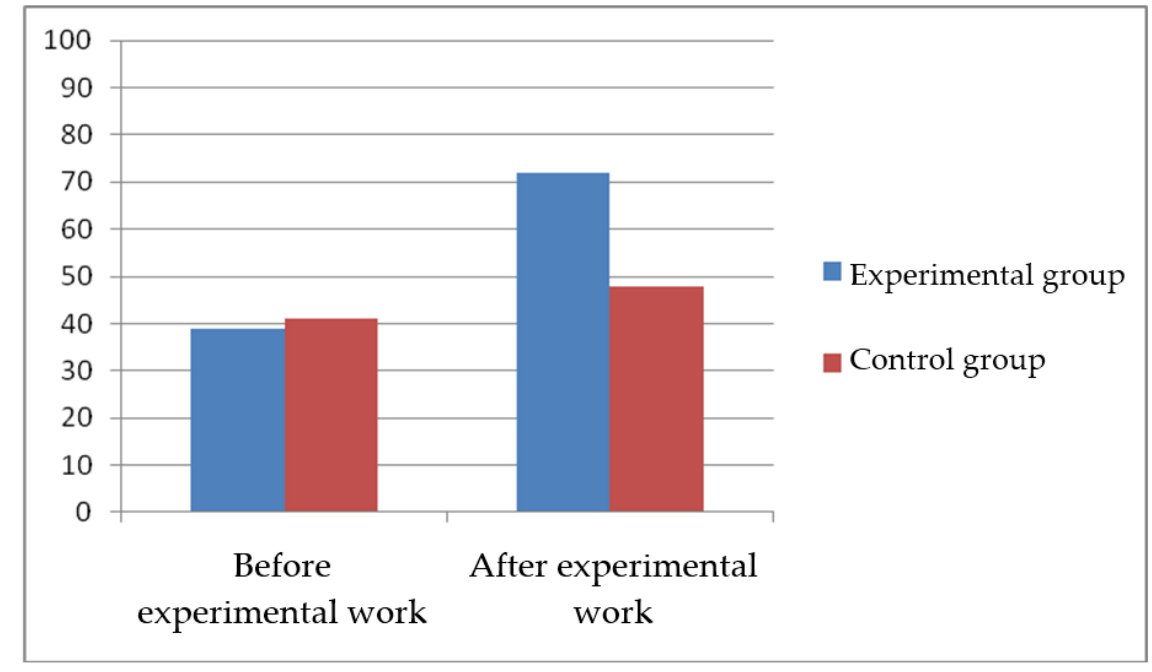

Figure 3. The level of ability to solve competence-oriented tasks in students of the experimental group (group average, \%)

The degree of mean value growth in the experimental group, which characterizes the quality of research, independent work, extracurricular activities of students and the level of general formation of professional competences, was checked during the final stage of the experiment. For this purpose, the method of expert assessments was used. We formed a group of experts consisting of four teachers whose specialty, qualifications and experience correspond to the purpose of the research. The experts analyzed research abstracts, articles and students' speeches during the defense of scientific projects and tracked the activity and productivity of the experiment participants during extracurricular activities such as QR-quests, QR-quizzes, QR-excursions, QR-dominoes, QR-lotto, etc. During the research period, students developed about five educational projects using QR-codes. As a result of data interpretation, it turned out that the experiment participants showed a significant increase in all subject competencies, and the final result exceeded the critical $70 \%$. 
Therefore, from the perspective of implementing the competence-based approach to the professional training of future chemists and economists, the use of this technology contributed to the formation of motivational-value, cognitive and activity-based components of professional competence. Moreover, students were actively developing information culture and the ability to use modern information technologies to ensure the quality of the educational process.

\section{Discussion}

The results of the experimental work showed that the possibilities of using QR-codes in the study of chemical and economic subjects are quite wide: due to the use of a scanning camera and a special passive visual marker, a certain interactive exchange of information takes place to significantly expand the horizons of productive processing of the material, supplement the information or improve perception (Mehendale et al., 2017; Ashford, 2010; Goldman, Pellegrino, 2015). Two-dimensional bar codes are used in the educational process not only at different stages of study, explanation, generalization, systematization or checking the material (Liu, Tan \& Chu, 2010; Lin, Teng, 2018; Lizunkov, Politsinskaya, Malushko, 2021) but also during the assessment of students' educational achievements. During such work, traditional and interactive forms of organizing educational activities can be combined (Liao \& Lee, 2010; Sharma et al., 2016). One should note that a working session with a QR-code is not limited by time because a student can save the scanned QR-code and continue work from the place where it was interrupted during the lesson (Almasalha \& Hirzallah, 2014; Karia, Hughes \& Carr, 2019).

The main forms of organizing training using QR technologies, which were used in the course of experimental work, included lectures, laboratory workshops, assessment of educational achievements and extracurricular activities. This is compared with the research made by Ashford (2010), who, at its lectures, QR codes were used to provide advance information from the predicted lecture (with accompanying material in the form of articles, research, list of recommended literature; visual material: photographs, diagrams, graphs, tables, maps, etc.); for the presentation of lecture material; to link to the forum where the lecture topic is discussed, questions are posed both during the lecture and after its completion; for a link to the questionnaire, where the lecture results are summed up (reflection), as can be seen in Almasalha and Hirzallah (2014). Meanwhile, during the laboratory workshops, it was practiced to create QR codes for safety, instructions for completing a laboratory-practical task, tags for explaining flowcharts, pictures, diagrams, fragments of an 
educational video, etc. This is supported by Sharma et al. (2016), when assessing educational achievements, the QR code was used to switch to test tasks, independent, control, examination work.

In extracurricular activities, QR-quests, QR-quizzes, QR-excursions, QR-dominoes, QRloto, etc. were used. During the experiment, we used new forms of presenting educational material using the QR-code technology. In particular, a methodological support package was developed according to the previously described forms of organizing education using QR technologies, the main requirements for the creation and use of which were: (1) pedagogical feasibility and purposeful use of QR-codes; (2) active work of each participant in the experiment during learning, expansion and enrichment of the information capacity of studying the subject; (3) differentiated approach with the consideration of the individual characteristics of the participants in the experiment; (4) availability and provision of stationary means for processing QR-codes for students who have limited access to mobile phones.

During the systematic work on the conceptual apparatus of the courses "Analytical Chemistry" and "History of Economics" with the involvement of a QR-dictionary, we could familiarize the students of the experimental group with the technology of creating and reading QR codes, analyzing the features and usability of a particular program (Almasalha \& Hirzallah, 2014). Thus, we found out that the application QR-code scanner does not read the Cyrillic alphabet, although it is very effective when working with the Latin alphabet (Baxter, McEntyre, Woodruff, 2011). The program IMGonline quickly and efficiently deals with the creation and decoding of QRcodes while offering great variety in choosing the color of the code picture. Creambee only generates codes but very conveniently and beautifully (Sharma et al., 2016). At the same time, all the listed programs work online both on a smartphone and on a computer, but for offline work, one can use the Code Two QR Code Desktop Reader (Baik, 2012). In general, there are many high-quality programs for generating and decoding QR codes that one can choose according to one's own needs.

In the process of teaching the professional courses "Analytical Chemistry" and "History of Economics", we used, when appropriate, coding of links to homework assignments or independent work. In the same way, some studies of Rayisyan et al. (2020) and of Gadzaova et al., (2021) shown that the studying of some digital versions of modern textbooks was organized directly in practical classes and at home. We also used the possibilities of the QR technology to increase the interest of students, providing links to interesting information from the history of chemistry, chemistry facts, etc. The results of the study confirmed the hypothesis that the use of the technology of creating and 
recognizing QR-codes in the learning process helps to increase the motivation and learning achievements of students - future specialists

Finally, the limitations of the study include the limited sample (82 students), as well as the preparation of methodological support within the framework of only two training courses (Analytical Chemistry, History of Economics) with a limited number of test items and competenceoriented tasks. The prospects for further research are the development of guidelines for the use of the QR-code technology in higher education institutions.

\section{Conclusion}

The experience of working with the use of the QR-code technology in teaching chemistry allows us to conclude that it is efficient when combined with traditional methods and contributes to the high-quality formation of students' skills and abilities. It allows implementing the ideas of individualization and differentiation of learning which are the main tasks of the modern education system. During the study, we managed to determine the essence of the QR-code technology and the possibilities of its use in the learning process; introduce the QR-code technology into the teaching process; confirm the usefulness of the work done in terms of increasing the motivation for learning and the growth of learning achievements during the professional training of future specialists in the context of a competence-based approach to this process.

The results of the pedagogical experiment indicate that the proposed methodology for using the QR-code technology in educational activities forms and develops professional competences, ensuring an increase in the quality indicators of the educational process. In general, this practice allows one to state that QR-codes can be used in the educational process as an interactive pedagogical tool that helps to organize efficient educational activities of students.

\section{References}

Abdol-Latif, L., Fadzil, M., Munira, T., \& San, N. (2012). Can the use of QR codes enhance mLearning in a blended learning environment? Journal Lifelong Learning Society, 8 (2), 1-20. https://doi.org/10.26857/JLLS.2012.08.8.2.1

Ally, M. (2013). Mobile learning: from research to practice to impact education. Learning and

Teaching in Higher Education: Gulf Perspectives, $10 \quad$ (2). https://doi.org/10.18538/LTHE.V10.N2.140 
Almasalha, F., \& Hirzallah, N. A. (2014). Students attendance system using QR code. International Journal of Advanced Computer Science and Applications, 5 (3), 75-79. https://doi.org/10.14569/IJACSA.2014.050310

Ashford, R. (2010). QR codes and academic libraries: Reaching mobile users. College and Research Libraries News, 71 (10), 526-530. https://doi.org/10.5860/crln.71.10.8454

Baxter, D., McEntyre, K., \& Woodruff, E.A. (2011). Using QR codes to enhance the personalized system of instruction. Journal of Physical Education, Recreation \& Dance, 82 (6), 45-47. https://doi.org/10.1080/08924562.2018.1395666

Belinskaya, S. I. (2016). The use of mobile applications in the learning process. Informatsionnyye tekhnologii i problemy matematicheskogo modelirovaniya slozhnykh system, 15, 97-102. https://www.elibrary.ru/item.asp?id=26738742\&

Chang, J. H. (2014). An introduction to using QR codes in scholarly journal. Science Editing, 1 (2), 113-117. https://doi.org/10.6087/kcse.2014.1.113

Chu, Y., \& Liu, T. (July 18-20, 2007). Handheld computer supported context-aware learning with $2 D$ barcodes. Seventh IEEE International Conference on Advanced Learning Technologies, Niigata, Japan. https://doi.org/10.1109/ICALT.2007.154

Coleman, J. (2011). QR codes: what are they and why should you care? Kansas Library Association College and University Libraries Section Proceedings, 1 (1), 16-23. https://doi.org/10.4148/culs.v1i0.1355

Creswell, J. W. \& Creswell, J. D. (2018). Research Design: Qualitative, Quantitative, and Mixed Methods Approaches. California : SAGE Publications, Inc.

De Pietro, O., \& Fronter, G. (July 4-6, 2012). Mobile tutoring for situated learning and collaborative learning in aiml application using qr-code. Sixth International Conference on Complex, Intelligent, and Software Intensive Systems, Palermo, Italy. https://doi.org/10.1109/CISIS.2012.154

Gadzaova, L. P., Goverdovskaya, E. V., Alisultanova, E. D., \& Moiseenko, N. A. (2021). organized online learning of students in universities and schools: didactics and methodology. Propósitos y Representaciones, 9, (3). http://dx.doi.org/10.20511/pyr2021.v9nSPE3.1181 
Goldman, S. R. \& Pellegrino, J. W. (2015). Research on Learning and Instruction: Implications for Curriculum, Instruction, and Assessment. Policy Insights from the Behavioral and Brain Sciences, 2 (1), 33-41. https://doi.org/10.1177/2372732215601866

Goyal, S., Yadav, S., \& Mathuria, M. (2016). Exploring concept of QR code and its benefits in digital education system advances. Computer Science and Information Technology (ACSIT), 3 (5), 452-456. https://doi.org/10.1109/ICACCI.2016.7732198

Hermanns, J., \& Schmidt, B. (2019). Developing and applying stepped supporting tools in organic chemistry to promote students' self-regulated learning. Journal of Chemical Education, 96 (1), 47-52. https://doi.org/10.1021/acs.jchemed.8b00565

Hinks, A., \& Sinkinson, C. (2011). Situated questions and answers: responding to library users with QR codes. Reference \& User Services Quarterly, 51 (1), 60-69. https://doi.org/10.5860/rusq.51n1.60

Huang, H.W., Wu, C.W., \& Chen, N.S. (2012). The effectiveness of using procedural scaffoldings in a paper-plus-smartphone collaborative learning context. Computers \& Education, 59 (2), 250-259. https://doi.org/10.1016/j.compedu.2012.01.015

Hughes, C. E., Stapleton, C. B., Hughes, D. E., \& Smith, E. M. (2005). Mixed reality in education, entertainment, and training. IEEE Computer Graphics and Applications, 26 (6), 24-30. https://doi.org/10.1109/MCG.2005.139

Jeon, Y.-J. (2015). A study on technology embedded english classes using qr codes. International Journal of Contents, 11 (1). https://doi.org/10.5392/IJoC.2015.11.1.001

Karia, C. T., Hughes, A., \& Carr, S. (2019). Uses of quick response codes in healthcare education: a scoping review. BMC Medical Education, 19, 456-467. https://doi.org/10.1186/s12909019-1876-4

Lai, H., Chang, C., Li, W., Fan, Y., \& Wu, Y. (2013). The implementation of mobile learning in outdoor education: Application of QR codes. British Journal of Educational Technology, 44 (2), 57-62. https://doi.org/10.1111/j.1467-8535.2012.01343.x

Law, C., \& So, S. (2010). QR codes in education. Journal of Educational Technology Development and Exchange, 3 (1), 85-100. https://doi.org/10.18785/jetde.0301.07

Lee, J. K., Lee, I. S., \& Kwon, Y. J. (2011). Scan \& learn! Use of quick response codes \& smartphones in a biology field study. The American Biology Teacher, 73 (8), 485-492. https://doi.org/10.1525/abt.2011.73.8.11 
Lin, K. Y., \& Teng, D. C. E. (2018). Using quick response codes to increase Students participation in case-based Learning courses. CIN: Computers, Informatics, Nursing, 36, 560-566. https://doi.org/10.1097/CIN.0000000000000462

Liu, T. Y., Tan, T. H., \& Chu, Y. L. (2010). QR Code and augmented reality-supported mobile english learning system. Mobile Multimedia Process, 5960, 37-52. https://doi.org/10.1007/978-3-642-12349-8_3

Liu, T., Tan, T., \& Chu, Y. (July 11-13, 2007). 2D Barcode and Augmented Reality Supported English Learning System. 6th IEEE/ACIS International Conference on Computer and Information Science, Melbourne, VIC, Australia. https://doi.org/10.1109/ICIS.2007.1

Lizunkov, V. G., Politsinskaya, E. V., \& Malushko, E. Y. (2021). Formation of supra-professional competencies sought in special economic development zones in graduates of technical universities. Perspectives of Science and Education, 50 (2), 145-161. https://doi.org/10.32744/pse.2021.2.10

MacRae, D. A. (2011). Introducing QR. Codes: linking print and digital content via smartphone. Neurosurgery, 68, 854-855. https://doi.org/10.1227/NEU.0b013e318214ccad

McCabe, M., \& Tedesco, S. (2012). Using QR codes and mobile devices to foster a learning environment for mathematics education. International Journal of Technology Inclusive and Inclusive Education, 1 (6), 37-43. https://doi.org/10.20533/ijtie.2047.0533.2012.0006

Mehendale, D., Masurekar, R., Nemade, S., \& Shivthare, S. (2017). To study the use of QR code in the classroom to enhance motivation, communication, collaboration and critical thinking. International Journal of Innovative Research in Computer and Communication Engineering, 5 (4), 6987-6993. https://doi.org/10.15680/IJIRCCE.2017.0504061

Monguillot, M., González, C., Guitert, M., \& Zurita, C. (2014). Mobile learning: a collaborative experience using QR codes. Mobile Learning Applications in Higher Education. Revista de Universidad y Sociedad del Conocimiento (RUSC), $11 \quad$ (1), 175-191. https://doi.org/10.7238/rusc.v11i1.1899

Okazaki, I., Li, H., \& Hirose, M. (2012). Benchmarking the use of QR code in mobile promotion: three studies in Japan. Journal of Advertising Research, 52 (1), 102-118. https://doi.org/10.2501/JAR-52-1-102-117 
Ozcelik, E., \& Acarturk, C. (2011). Reducing the spatial distance between printed and online information sources by means of mobile technology enhances learning: Using 2D barcodes. Computers \& Education, 57 (3), 2077-2085. https://doi.org/10.1016/j.compedu.2011.05.019

Pulliam, B., \& Landry, C. (2011). Tag, you're it! Using QR codes to promote library services. The Reference Librarian, 52 (1/2), 68-74. https://doi.org/10.1080/02763877.2011.521883

Robertson, C., \& Green, T. (2012). Scanning the potential for using QR codes in the classroom. Techtrends Linking Research \& Practice to Improve Learning, 56 (2), 11-12. https://doi.org/10.1007/s11528-012-0558-4

Sarp, E. (2017). Using QR codes as a resourceful ICT tool in the ELT classroom. European Journal of Language and Literature Studies, 3 (1), 49-55. https://doi.org/10.26417/ejls.v7i1.p49-55

Sergeeva, M. S., Lukashenko, D. V., Burnakin, M. N., Bedenko, N. N., \& Kolchina, V. V. (2020). The pedagogical technology of manager: professional potential development in the system of business education. Turismo: Estudos \& Práticas, 3, 1-7. http://natal.uern.br/periodicos/index.php/RTEP/article/view/1882/1742

Sharma, R., Jain, A., Gupta, N., Garg, S., Batta, M., \& Dhir, S. K. (2016). Impact of self-assessment by students on their learning. International Journal of Applied and Basic Medical Research, 6, 226-229. https://www.ijabmr.org/text.asp?2016/6/3/226/186961

Shustack, L. (2018). Virtually engaging millennial nursing students through QR codes. Journal of Nursing Education, 57, 699-700. https://doi.org/10.3928/01484834-20181022-15

Solovieva, O. V., Palieva, N. A., Borozinets, N. M., Kozlovskaya, G. Y., \& Prilepko, J. V. (2020). Development of digital intelligence among participants of inclusive educational process. Propósitos y Representaciones, 8 (2). http://dx.doi.org/10.20511/pyr2020.v8nSPE2.675

Sungkur, R. K., Neermul, V., \& Tauckoor, V. (November 28-29, 2016). Exploring the educational potential of $Q R$ codes. International Conference on Advances in Computing and Communication Engineering (ICACCE), Durban, South Africa. https://doi.org/10.1109/ICACCE.2016.8073777

Thorne, T. (2016). Augmenting classroom practices with QR codes. TESOL Journal, 7 (3), 746754. https://doi.org/10.1002/tesj.257

Uluyol, C., \& Agca, R. K. (2012). Integrating mobile multimedia into textbooks: 2D barcodes. Computers \& Education, 59 (4), 1192-1198. https://doi.org/10.1016/j.compedu.2012.05.018 
Walsh, A. (2009). Quick response codes and libraries. Library Hi Tech News, 26 (5/6), 7-9. https://doi.org/10.1108/07419050910985255

Yip, T., Melling, L., \& Shaw, K. (2016). Evaluation of an online instructional database accessed by QR codes to support biochemistry practical laboratory classes. Journal of Chemistry Education, 93 (9), 1556-1560. https://doi.org/10.1021/acs.jchemed.6b00184 